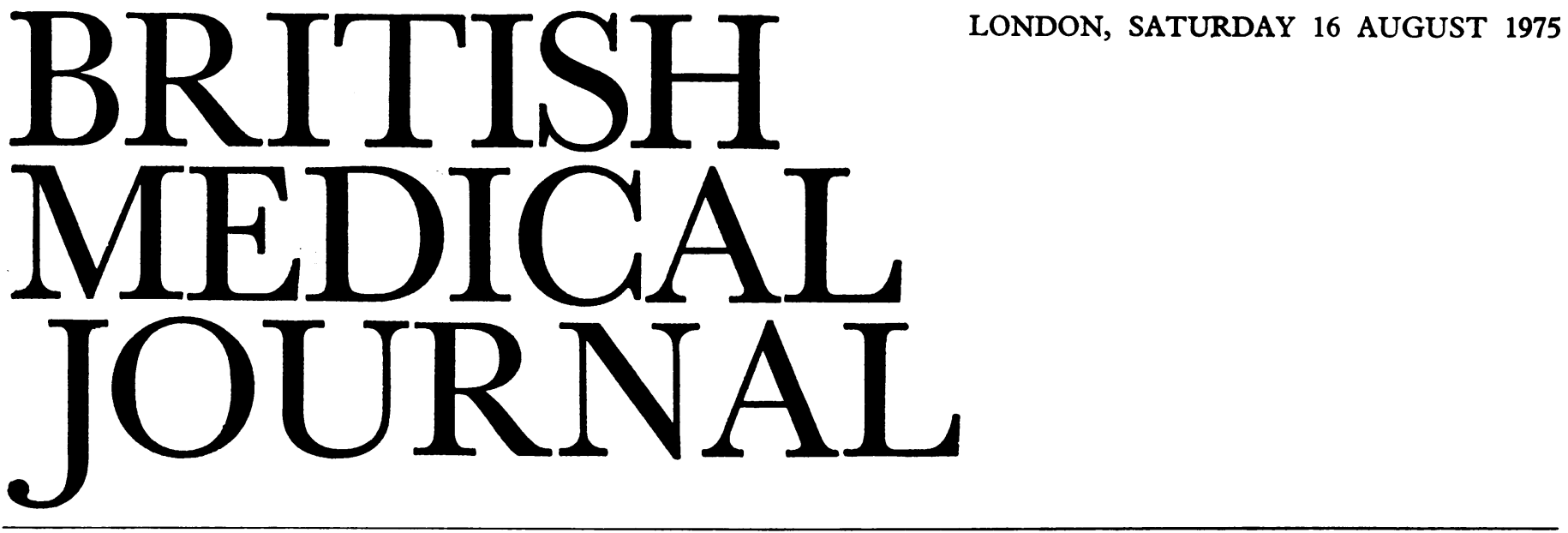

The illnesses arising from shellfish are usually those associated with sewage. From time to time typhoid fever, paratyphoid fever (rarely), cholera (recent outbreaks in Italy and Portugal), and hepatitis (on epidemiological evidence) have originated from shellfish living in estuaries and feeding in water polluted by faecal material. ${ }^{1}$ The more enlightened oyster farmers make sure that if the water is not pure then the shellfish are subjected before sale to cleaning procedures-either a sojourn in water made pure by chlorination or a period in tanks filled with water circulating over a dam and exposed at that point to ultraviolet light. ${ }^{2}$

It is logical to assume that an organism indicative of faecal pollution such as Escherichia coli could be used as a marker for the degree of pollution or purity achieved by shellfish. ${ }^{3}$ Food hygienists rested on this assurance until oysters were lifted from the bed of the river Tamar after many years of abolition; they were put through tanks of river water subjected to a small ultraviolet source and sold to the public. Illness occurred almost immediately in sporadic cases and small outbreaks, and in volunteers who, disbelieving the stories, took oysters from the tanks and ate them. Known intestinal pathogens (including viral agents) were not found in the oysters (faecal specimens were rarely received owing to late reporting) and the illness was atypical in certain respects. The predominant symptoms were nausea, vomiting, and abdominal pain, diarrhoea coming on rather later in the patients who were severely ill. ${ }^{4}$ Pyrexia was not a feature but pulse rates were raised. Some patients complained of headache and pains in the legs. In other outbreaks loss of weight and malabsorption were described. The duration of illness was usually 18-50 hours, but symptoms such as malaise and lack of appetite occasionally persisted for some days. ${ }^{5}$ The incubation period was mostly 35 to 45 hours, but symptoms also occurred within 10-24 hours and as late as 50-60 hours; even 5 days' incubation was described.

Other batches of oysters picked from beds further down the coast gave rise to similar incidents, and in all some eight outbreaks were reported. ${ }^{5}$ The danger from such oysters on aircraft has been described by Preston. ${ }^{6}$

The quality of the oysters as judged by the $E$. coli count was good, but the general bacteriological condition was usually poor, with high counts of miscellaneous organisms including many moderately-low-temperature water vibrios. At that time neither Vibrio parahaemolyticus nor non-cholera (N.A.G.) vibrios were found. Laboratory techniques have since improved, and nowadays reports of $V$. parahaemolyticus in seafoods are fairly common, ${ }^{7}$ though reports of $V$. parahaemolyticus food poisoning in Britain are still relatively few. ${ }^{8} 9$ The agent responsible for the oyster syndrome has not been named. It was associated with oysters from heavily polluted areas and small purification plants adequately dealing with $E$. coli and other enterobacteriaceae in the gut but unable to clear large numbers of other micro-organisms from gills and flesh. No harm came from eating cooked oysters.

Oysters grow well in polluted waters, and it is sometimes suggested that produce from such good growing areas should be relaid in purer waters. The industry is small, but many fishermen rely for part of their living on the sale of shellfish and everything possible should be done to help them. The ratio between counts of bacteria at $20^{\circ} \mathrm{C}$ and $37^{\circ} \mathrm{C}$ may be a useful guide ${ }^{10}$ to assessing a public health risk, the higher the count at $37^{\circ} \mathrm{C}$ the greater the risk. The types of organisms should also be carefully studied. Perhaps guidelines could be given for shellfish areas based not only on water but also on examination of fish, and not only on $E$. coli but also on the predominant bacterial flora.

Anyone who becomes ill after eating shellfish should be asked to submit stool specimens to the nearest district physician or public health laboratory as soon as possible, as there is still much to learn about vibrio and viral infections which might arise from shellfish. More detailed epidemiological studies are required to associate areas of growth and methods of purification of shellfish with outbreaks or with freedom from food poisoning incidents. Stories of illness from oysters and other shellfish are heard frequently, but authoritative records and results of thorough and full examinations of samples of the shellfish, the environment, and the stools of those affected are rarely available.

Outbreaks of food poisoning which arise from cockles and winkles sold from shops and stalls are more simply explained by the growth of pathogens such as Staph. aureus (from hands) and $V$. parahaemolyticus (from the raw to the cooked product) to a level sufficient to initiate symptoms. The higher the atmospheric temperature the greater the hazard of long periods of unrefrigerated storage. While dead oysters and mussels can be recognized by their open shells, there is no such guide to the danger of bacterial growth in cooked seafoods. The inhabitants of a country with occasional bursts of hot weather 
should be selective in their choice of food at such times. Countries continually exposed to high temperatures are more aware of the dangers.

Another hazard is that of paralytic poisoning associated with molluscan shellfish and due to saxatoxin, a neurotoxin produced by marine dinoflagellates and, in particular, Gonyaulax tamarensis. Outbreaks are rare in Britain. ${ }^{11-13}$ They occur in north and north-eastern coastal regions, where a combination of the Gulf Stream, tides, and plankton bring occasional blooms of protozoa to our shores. Certain laboratories keep watch over shellfish in these areas by routine screening for neurotoxins. ${ }^{14}$

1 Wilson, G. S., and Niles, A., Topley and Wilson's Principles of Bacteriology, Virology and Immunity. 6th ed., p. 2660. London, Edward Arnold, 1975.

2 Wood, P. C., Fishery Investigations, Ser. II Vol. 23, No. 6, Ministry of Agriculture, Fisheries and Food. London, H.M.S.O., 1961.

3 Clegg, L. F. L., and Sherwood, H. P., Fournal of Hygiene, 1947, 45, 504.

4 Gunn, A. D. G., and Rowlands, D. F., Medical O fficer, 1969, 122, 75.

5 British Medical fournal, 1970, 2, 428.

6 Preston, F. S., Aerospace Medicine, 1968, 39, 519.

7 Barrow, G. I., and Miller, D. C., Lancet, 1972, 1, 485.

8 Peffers, A. S. R., et al., Lancet, 1973, 1, 143.

- Hooper, W. L., Barrow, G. I., and McNab, D. J. N., Lancet, 1974, 1,1100 .

10 Ayres, P. A., Fournal of Hygiene, 1975, 74, 431.

11 Gemmill, J. S., and Manderson, W. G., Lancet, 1960, 2, 307.

12 McCollum, J. P. K., et al., Lancet, 1968, 2, 767.

13 Ayres, P. A., Environmental Health, 1975, 83, 261.

14 Ingham, H. R., Mason, J., and Wood, P. C., Nature, 1968, 220, 25

\section{Gifted Children}

On 8-12 September a World Conference on Gifted Children will be held in London. It is the first conference of its kind to take place in Britain, and is intended to be the forerunner of a series of world meetings in different countries. The National Association for Gifted Children, which is promoting the conference with the co-operation of the Department of Education and Science and the Department of Health and Social Security, was founded in 1966 with the aim of helping young people fulfil their potential. The motivation for this movement is the belief that gifted children are at risk of underachievement and social maladjustment.

What exactly are "gifted children?" From the vast numbers of contradictory publications on the subject, largely the work of educationalists and psychologists, it seems we must distinguish the gifted-those of superior intellectual abilityfrom the talented-those with exceptional skill in bodily co-ordination or aesthetic sensibility, in mathematics, music, art, dance, or athletics. Spearman succinctly clarified this issue many years ago with his concept of " $g$," general intelligence and "s," special intelligence. Creativity is a more difficult matter. An intelligent child may lack originality; rarely, unusual creativity may coexist with modest intellectual endowment. ${ }^{1}$

Many authors seem to believe-with what evidence is not clear-that creativity can be initiated by training. It does seem probable, however, that creative potential may be stifled by social, emotional, and intellectual deprivation. ${ }^{2}$ Is it possible that creativity may be stimulated by childhood experiences of frustration and suffering? The early histories of many great men and women might seem to suggest so; but perhaps they were all potentially even greater.

What about the traditional tag that "genius is akin to madness"? Gifted children are not a homogeneous group, and among them as among all other sections of the child population are to be found a minority of individuals with emotional and personality problems. There is, however, considerable evidence that there are fewer neurotic tendencies, more selfsufficiency, and less submissiveness among the gifted. These children also compare favourably with the average as regards physical characteristics. ${ }^{3}$

Nevertheless, for some gifted children the fact of being different creates difficulties. They may become bored with a school curriculum geared to the average or just above it. They may under-achieve deliberately in order to find acceptance in the group. Their giftedness may never be suspected. In considering their educational needs Dunlap ${ }^{4}$ stated, "Children with high mental ability of whatever kind and degree require significantly different education from the majority . . . In the past far-sighted educators have permitted them to advance at a faster than average pace, to study together, to explore far beyond the ordinary curriculum." Yet the National Association for Gifted Children is opposed to segregated schooling except for music and ballet. For the parents of every such child there are difficult decisions to be taken and little reliable advice available. The need to nurture the most talented seems clear enough; as for the gifted, judgement may be reserved. The forthcoming conference should be of particular interest to paediatricians, school doctors, and children's psychiatrists as well as to teachers and psychologists.

1 Nash, J., Developmental Psychology. London, Prentice-Hall, 1970.

2 Pringle, M. L. K., Able Misfits. London, Longmans, 1970

${ }^{3}$ Lucito, L. J., in Exceptional Children in Schools, ed. L. M. Dunn. New York, Holt, Rinehart and Winston, 1963.

${ }^{4}$ Dunlap, J., in Education of Exceptional Children and Youth, eds. W. M. Cruickshank and G. O. Johnson. New Jersey, Prentice-Hall, 1967.

\section{Rehabilitation after Acute Myocardial Infarction}

Everyday domestic, social, psychological, and economic pressures dictate that patients who survive acute myocardial infarction should return as quickly as possible to a normal way of life. Some modification of their work may be needed at first, but at least $60 \%$ of such patients resume work within four months, ${ }^{1}$ and $85 \%$ are working again within ten months of their heart attack ${ }^{2}$ without the assistance of either specialized rehabilitation centres or a formal training programme. In some patients fear of sudden death or recurrence of ill-health and ill-conceived ideas of the cause of their heart condition, combined with lack of either sympathetic or informed professional guidance, may delay or prevent satisfactory rehabilitation and can lead to chronic invalidism. ${ }^{3}$ Ironically, severe physical incapacity as the consequence of heart failure or incapacitating angina is uncommon after the first acute myocardial infarction in the working age group. ${ }^{4}$

International cardiological opinion on the topic has been summarized by the Working Party of the Royal College of Physicians (p. 417), but not much reliable factual information is available. General practitioners and physicians will, no doubt, want to read the full report from the College; for this abridged report contains little detailed advice on the most appropriate way of achieving optimum physical and mental fitness in this ever-increasing group of patients. Though a 